\title{
Is Climate Change a Moral Issue? Effects of Egoism and Altruism on Pro-Environmental Behavior
}

\author{
Igor Knez \\ Department of Social Work and Psychology, University of Gävle, Gävle, Sweden \\ Email: igor.knez@hig.se
}

Received 12 April 2016; accepted 11 June 2016; published 14 June 2016

Copyright (C) 2016 by author and Scientific Research Publishing Inc.

This work is licensed under the Creative Commons Attribution International License (CC BY). http://creativecommons.org/licenses/by/4.0/

(c) (i) Open Access

\begin{abstract}
Do value orientations of egoism and altruism affect pro-environmental behaviour? The answer is "yes", according to the results obtained. Corresponding to the self-benefit goal hypothesis, egoistic individuals (rated "high" on egoism) were shown to perceive having less control; that is, they believed that it was too difficult as well as pointless to do much about environmental issues. They were also less willing to pay higher taxes and prices as well as cut their standard of living for environmental protection. In contrast, and along the lines of empathy-altruism hypothesis, altruistic individuals (rated "high" on altruism) were shown to perceive having more control and showed a greater willingness to make sacrifices. Egoistic compared to altruistic individuals were also shown to be less prepared not to drive their car for environmental reasons. This suggests that a deontic proposition of "we should behave pro-environmentally" is recognized as a moral issue by the altruistic individuals, but not by the egoistic ones. Accordingly, when promoting sustainable policy and "ethical" decision making, it is important to take into account imperatives of egoism and altruism involved in climate-change-related decision making.
\end{abstract}

\section{Keywords}

Climate Change, Egoism, Altruism, Pro-Environmental Behaviour

\section{Introduction}

Information about earthquakes, tsunamis, heat waves and storms is an ingredient of everyday news, indicating that climate change may have a profound impact on human behaviour and society (Saad, 2002; Schmuck \& Vlek, 2003; Koppe, Jendritzky, Kovats, \& Menne, 2004; UNWTO, 2008; IPCC, 2007). This will engender pol- 
icy and pro-environmental actions (UNCED, 1992; WRI, 2000) for sustainable development, as well as for "intergenerational” behaviour (Wade-Benzoni \& Tost, 2009). In other words, we are the ones that shape the foundations for our children's future (Pelletier, Lavergne, \& Sharp, 2008), given the fact that "slowness of environmental changes makes their direct sensory perception impossible.” (Bonnes \& Bonaiuto, 2002: p. 35; see also Swim, Stern, Doherty, Clayton, Reser, Weber, Gifford, \& Howard, 2011).

Besides the media, the phenomenon of climate change is disseminated by politicians and scientists (Wilson, 2000); a knowledge that is by definition scientifically uncertain (Stern, 2006; Marx, Weber, Orlove, Leiserowitz, Krantz, Roncoli, \& Phillips, 2007; Dutt \& Gonzalez, 2012) and by that frequently misunderstood (Böhm \& Pfister, 2001). This might lead to public debates that do not "always seem to match the seriousness of the problem identified by scientists” (Corner \& Hahn, 2012: p. 199). A lack of commitment is furthermore indicated among politicians and stakeholders (Weaver, 2006; Willms, 2007; Scott, Freitas, \& Matzarakis, 2009; Scott, Peeters, \& Gössling, 2010).

Consequently, both knowledge about climate change and confidence in that knowledge may vary across groups of individuals, such as scientists, journalists, politicians and laypersons (Sundblad, Biel, \& Gärling, 2009). Knez, Thorsson and Eliasson (2013) have, for example, shown that: 1) Experts were least concerned for, and afraid of, climate change impact; 2) Youngest participants were found to be most, and oldest least, concerned for their future; 3) Women were shown to be more concerned for, and afraid of, the consequences of climate change; 4) Men and the least educated participants believed their jobs to be more threatened by environmental laws and protection, and the latter believed moreover that the claims about climate change were exaggerated.

Given this, psychological research on environmental issues and sustainable development has reported findings on such different phenomena as: environment-related risk judgment and behaviour (Bonnes \& Bonaiuto, 2002; Sundblad, Biel, \& Gärling, 2007); morals and ethics (Ehrich, 2002; Karpiak \& Baril, 2008); resource dilemmas (Hardin, 1968; Van Vugt, 2002; Schmuck \& Vlek, 2003; Kortenkamp \& Moore, 2006; Biel \& Thögersen, 2007; Aitken, Chapman, \& McClure, 2011); value orientations (Schultz, Gouveia, Cameron, Tankha, Schmuck, \& Franek, 2005; Hansla, Gamble, Juliusson, \& Gärling, 2008); and affect (Boehnke, Fuss, \& Rupf, 2001; Olofsson \& Öhman, 2006; Ojala, 2007; Knez, 2013).

It is also indicated that people may assess local vs. global environmental problems as less worrying (Garcia-Mira, Real, \& Romay, 2005). According to Loewenstein, Weber, Hsee and Welch (2001), feelings related to environmental problems can be conceptualized as anticipatory (fast, bottom-up, visceral processes) and anticipated emotions (slow, top-down, analytically driven processes), indicating that less concern for climate change may be due to lack of personal experience of that phenomenon (no own visceral reactions of anticipatory emotions) (Weber, 2006). In consequence, and according to the "risk as feelings" hypothesis (Loewenstein et al., 2001), processes of decision and policy making (Sage, 1992) regarding climate change are not only cognitive but emotional, involving a distinction between experience-based (anticipatory affect) and description-based (anticipated affect) emotional appraisals (Slovic, Finucane, Peters, \& MacGregor, 2002; Leiserowitz, 2006).

\subsection{Pro-Environmental Behaviour}

Pro-environmental behaviour alludes to activities that are oriented towards sustainability (Kaiser, 1998; Gardner \& Stern, 1996; Di Castri, 2000; Stern, 2000a; Bonnes \& Bonaiuto, 2002; Steg \& Vlek, 2009), such as behavioural control, willingness to sacrifice and action behaviour (Oreg \& Katz-Gerro, 2006) as well as collectiveand self-efficacy (Lepore \& Evans, 1996).

In general, the first three types of behaviours/measures are deduced from theories of planned behaviour (Ajzen, 1991), reason action (Fishbein \& Ajzen, 1975; Ajzen \& Fishbein, 1980) and norm activation (Schwartz, 1970, 1977), and the last two from theories of cognitive stress (Lazarus, 1966, 1991; Bandura, 1997). Accordingly, they represent environment-related behavioural intention (behavioural control and willingness to sacrifice), action behaviour ("pure” pro-environmental behaviour) and resource appraisal (collective-vs. self-efficacy; that is, how much can we vs. I contribute to "solve" the environmental problem?-see Iwata, 2002; Homburg \& Stolberg, 2006).

Several authors have extended Schwartz’ (1992, 1994) (see also Lewin, 1951; Batson, Van Lange, Ahmad, \& Lishner, 2003) work on values, beliefs and concerns including environmental issues as well (Stern, 2000b; Schultz, 2001; Oreg \& Katz-Gerro, 2006; Hansla et al., 2008). This suggests that, for example, a value orienta- 
tion of egoism might be positively associated with awareness of climate change consequences for oneself (belief) and self-related affect (concern).

\subsection{Ethics of Climate Change}

Do people consider the climate change issue as an ethical question of "right and wrong"? The Henry J. Kaiser Family Foundation (2000) showed that $64 \%$ of Americans considered the protection of the environment to be a moral issue. Others too have argued that the phenomenon of climate change is an ethical problem (Broome, 2008; Davidson, 2008; Jamieson, 2009). In line with this, several studies have reported that we might consider the climate change issue to be moral (Fogg, 2000; Ehrich, 2002; Corral-Verdugo, Bechtel, \& Fraijo-Sing, 2003; Hatcher, 2004; Karpiak \& Baril, 2008), conceptualized in terms of personal obligations to do the "right thing" for the sake of the environment (Ehrich, 2002; Nordlund \& Garvill, 2003; Kaiser, 2006; Kaiser, Schultz, Berenguer, Corral-Verdugo, \& Tankha, 2008; Karpiak \& Baril, 2008; Scherbaum, Popovich, \& Finlison, 2008).

A deontic (should/should not) proposition of "we should behave pro-environmentally" may, however, not be conceived as a moral matter, but rather a question of opinion as with many other deontic propositions (Bucciarelli, Khemlani, \& Johnson-Laird, 2008). Why some of us do not define climate change as a moral imperative may also be due to the cognitive and affective complexity embedded in this topic, which may lead to a non-activating of the "human moral alarm system" (Markowitz \& Shariff, 2012).

However, in Kantian terms: Can our actions include "true moral worth” (Stich, Doris, \& Roedder, 2010; Batson, 2011)? Many philosophers and economists (Miller, 1999) have advocated the view that our supportive behaviours are ultimately motivated by self-interest. Our willingness to accept short-term costs in order to benefit others is perhaps just a strategy to profit oneself in the long run, e.g. being considered as a generous person (Hardy \& Vugt, 2006). This may indicate a phenomenon of psychological egoism, that concerns for others are not ultimate, but rather instrumental for one’s own benefit (Sober \& Wilson, 1998; Stich et al., 2010).

Alluding to this ancient query of the existence of true altruism (Rushton \& Sorrentino, 1981; Schroeder, Penner, Dovidio, \& Piliavin, 1995; Cialdini, Brown, Lewis, Luce, \& Neuberg, 1997; Maner, Luce, Neuberg, Cialdinin, \& Sagarin, 2002; Batson et al., 2003; Fehr \& Fischbacher, 2003; Elster, 2005), Knez (2013) showed that egoistic individuals (rated "high" on egoism) were most concerned about environment-related myself issues and that altruistic individuals (rated "high" on altruism), in contrast, were most concerned about environment-related others issues. This indicated a self-benefit-goal-motive (Batson, 1995) in the former group and a pro-socialgoal-motive (Batson, 1991, 1998) in the latter. Additionally, in Schroeder, Roskies and Nichols' (2010) terms, we may say that egoists are motivational instrumentalists (moral action stems from one's wants) and that altruists are motivational personalists (moral action stems from one's knowledge ("good character") of what is right). Alternatively, that instrumental vs. intrinsic values (Light \& Katz, 1996; Leopold, 1949/1987) about the worth of milieu is indicated in egoists and altruists respectively.

Given this, Knez (2013) concluded that when encouraging sustainable policy and development (e.g. UNCED, 1992; UNWTO, 2008; Menzel \& Bögeholz, 2010) we should pay more attention to people’s moral obligations regarding environment-related selfishness and unselfishness, suggesting that we have to learn which issues are moral and which are not (Bucciarelli et al., 2008) in order to promote "ethical" decision making (Jones, 1991; Hershfield, Cohen, \& Thompson, 2012).

\subsection{Present Study}

Given the above (e.g. Batson, 2011; Knez, 2013), it might be suggested generally that people with strong egoistic values will be motivated more by their self-benefit-goals and therefore will perceive less behavioural control and sacrifice. Conversely, people with strong altruistic values will be motivated more by their empathy-related-goals and by that will perceive more behavioural control and sacrifice. In addition, altruists will trust more in collective than in self-efficacy. Egoists will trust more in self-efficacy and also in collective-efficacy (according to the phenomenon of "unintended consequences" Batson et al., 2003) because it will, in the long run, benefit oneself (Cialdini et al., 1997).

Accordingly, the aim was to investigate effects of environment-related egoism vs. altruism on pro-environmental behaviours (perceived behavioural control, willingness to sacrifice, action behaviour and collective- and self-efficacy), including the following two hypotheses:

Hypothesis 1. Participants assessed as "high" vs. "low" on egoism will relate more to the self-benefit goal is- 
sues (Batson, 1995), meaning that they:

1) Will perceive less behavioural control. (That is, they will agree more with statements such as "It is just too difficult for someone like me to do much about the environment." and "There is no point in doing what I can for the environment unless others do the same.”)

2) Will be less willing to sacrifice.

3) Will show less action behaviour.

4) Will believe more in collective efficacy.

5) Will believe more in self-efficacy.

Hypothesis 2. In contrast and according to the empathy-altruism hypothesis (Batson, 1991, 1998), participants assessed as "high" vs. "low" on altruism will act more unselfishly, meaning that they:

a) Will perceive more behavioural control. (That is, they will agree less with statements such as, "It is just too difficult for someone like me to do much about the environment." and "There is no point in doing what I can for the environment unless others do the same.”)

b) Will be more willing to sacrifice.

c) Will show more action behaviour.

d) Will believe more in collective efficacy.

e) Will believe less in self-efficacy.

\section{Method}

\subsection{Sample}

A total of 1000 households located within the City of Gothenburg, Sweden $\left(57^{\circ} 42^{\prime} \mathrm{N}, 11^{\circ} 58^{\prime} \mathrm{E}\right)$ with a population of ca. 500,000 were sent a "climate survey". They were randomly identified from a register of population. The survey comprised a number of sections including questions about demographic variables, climate, climatechange-related behaviours, attitudes, etc. Data on environment-related egoism vs. altruism and pro-environmental behaviours will be reported in this article. After two contacts 528 replies were obtained; involving 53\% women and 47\% men, distributed across six age groups of $\leq 25$ (10\%), 26 - 35 (16\%), 36 - 45 (14\%), 46 - 55 (14\%), 55 - 65 (16\%) and 66+ (30\%).

\subsection{Measures}

Egoism vs. altruism. Climate-change-related beliefs grounded in environment-related egoistic vs. altruistic value orientations were used as a measure of egoism vs. altruism, derived from Hansla, Gamble, Juliusson, \& Gärling, 2008 and Knez et al. (2013): Egoism (1) Laws that protect the environment limit my choices and personal freedom and (2) Protecting the environment will threaten jobs for people like me ( $\alpha=.64)$; Altruism (3) Effects of climate change on public health are worse than people realize and (4) Pollution generated in one country harms people all over the world $(\alpha=.56)$. Participants were asked to respond to these statements on a 7-point scale ranging from 1 (completely disagree) to 7 (completely agree). These scales were first transformed into a general variable of egoism vs. altruism by calculating a mean value for the statements (1) + (2) and (3) + (4) respectively. Subjects lower than $4(1-3)$ were considered to be "low" and those higher than $5(5-7)$ were considered to be "high" on the respective independent variable of Egoism (low vs. high) vs. Altruism (low vs. high).

Psychological research usually recommends three types of method for splitting a continuously scaled variable: 1) At the midpoint of the scale; 2) At the median; and 3) At the top and bottom third, which is used in the present paper. This is because the aim of this study was to investigate pro-environmental behaviour polarized by "high" vs. "low" egoistic and altruistic individuals respectively; not including undecided ones in the middle of the scale (e.g. Knez, 2005; Knez, 2013; Knez \& Thorsson, 2006). According to DeCoster, Iselin and Gallucci (2009: p. 364) a dichotomization of a continuous variable/measure is justified when using "extreme group analysis"; that is, including only individuals scoring low and high on a scale, and thereby investigating contrasting positions.

Pro-environmental behaviour. Five types of measure were used; the first three derived from Oreg and KatzGerro (2006) and the last two from Homburg and Stolberg (2006):

1) Perceived behavioural control comprising items "It is just too difficult for someone like me to do much about climate change." and "There is no point in doing what I can for climate change unless others do the same." 
( $\alpha=$.55)-responding on a 7-point scale ranging from 1 (completely disagree) to 7 (completely agree).

2) Willingness to sacrifice comprising items "I am willing to pay much higher taxes to protect the environment.", "I am willing to pay much higher prices to protect the environment." and "I am willing to accept cuts in standard of living to protect the environment." ( $\alpha=.82$ )-responding on a 7-point scale ranging from 1 (completely disagree) to 7 (completely agree).

3) Action behaviour comprising items "How often do you sort glass, tins, newspaper, etc. for recycling?" and "How often do you cut back on driving a car for environmental reasons?"-responding on a 5-point scale ranging from 1 (never) to 5 (daily).

4) Collective efficacy comprising items "I am sure that we can achieve progress, because we are pulling in the same direction.", "I am confident that together we can solve the problem of climate change." and "We can come up with creative ideas to solve climate change problems effectively, even if the external conditions are unfavourable.” ( $\alpha=.53$ )-responding on a 7-point scale ranging from 1 (completely disagree) to 7 (completely agree).

5) Self-efficacy comprising items "Whatever happens in terms of climate change, I will be able to handle it." "I don't worry much about climate change consequences because I trust in my ability to cope with them." and "I know how to cope with warnings about climate change in everyday life." $(\alpha=.78)$-responding a 7-point scale ranging from 1 (completely disagree) to 7 (completely agree).

\subsection{Design}

A non-equivalent comparison-group quasi-experimental design (McGuigan, 1983) was used. Compared with a "true experiment" (Liebert \& Liebert, 1995), this means that the inferences drawn about the causal relationships between independent and dependent variables are considered to be weaker.

Independent variables. Two independent variables of Egoism (low vs. high; 360 vs. 46 participants) and Altruism (low vs. high; 51 vs. 316 participants) were involved in the study. Due to 1) the cross-sectional data and 2) the aim of this study, i.e. to investigate pro-environmental behaviour polarized by "low" vs. "high" egoistic and altruistic individuals respectively, two one-way analyses of variance were performed involving independent variables of Egoism and Altruism respectively. Thus, the aim of this study was not to investigate any interactions between "low" vs. "high" egoistic vs. altruistic subjects, but to analyse differences related to "low" vs. "high" individuals in respective value orientation of egoism and altruism.

Dependent variables included 13 pro-environmental behaviour items, comprising 2 perceived behavioural control +3 willingness to sacrifice +2 action behaviour +3 collective efficacy +3 self-efficacy items.

\section{Results}

The objective was to examine the effects of "low" vs. "high" egoism vs. altruism on climate-change related to pro-environmental behaviour. Before proceeding with the statistical analyses, we have to ensure that the classification procedure used (see Method/Measures/Egoism vs. altruism) provides a good test of the polarized "low" vs. "high" positions in egoism and altruism respectively. In line with Knez (2013), this was done by: 1) A MANOVA testing for the interaction effects of egoism (low vs. high) $\mathrm{X}$ altruism (low vs. high) on pro-environmental behaviour (perceived behavioural control, willingness to sacrifice, action behaviour, collective efficacy, and self-efficacy); and 2) A regression analysis testing for the degree of relationship between the two general scales (see Method/Measures/Egoism vs. altruism) of egoism and altruism.

MANOVAs showed no significant interaction (except for action behaviour) effects of egoism and altruism on pro-environmental behaviour (perceived behavioural control, $p>.82$; willingness to sacrifice, $p>.29$; action behaviour, $p>.05$; collective efficacy, $p>.07$; self-efficacy, $p>.66$ ); neither were significant associations between the two scales of egoism and altruism indicated $(p>.61)$ by the regression analysis.

Accordingly, and in line with Knez (2013), environment-related egoism and altruism are indicated to be unrelated, meaning that we can proceed safely analysing the "contrasting positions" of "low" vs. "high" individuals in respective value orientation of egoism and altruism on climate-change-related pro-environmental behaviour.

$S D$ differences between the cells (unequal cell sizes of low vs. high egoism/altruism) for the dependent variables were between .0 and .2, thus indicating no, or a very small, potential distortion of $\alpha$ levels (Tabachnick \& Fidell, 1989). Also, the statistical software SPSS uses the "Type III model” as default, taking into account un- 
weighted means.

Given the above, data were subjected to MANOVAs comprising two result sections related to Hypotheses 1 and 2 respectively (see Introduction): 1) Effects of Egoism on Pro-Environmental Behaviour and 2) Effects of Altruism on Pro-Environmental Behaviour.

\subsection{Effects of Egoism on Pro-Environmental Behaviour}

A MANOVA was performed for each of the five pro-environmental behaviours: "perceived behavioural control" (2 items), "willingness to sacrifice" (3 items), "action behaviour" (2 items), "collective efficacy" (3 items) and "self-efficacy" (3 items).

A main significant effect on perceived behavioural control was obtained-Wilk's Lambda $=0.95, F(2,403)=$ $10.65, p<.01, \eta^{2}=.05$. This effect was associated with both items "It is just too difficult for someone like me to do much about climate change." $\left(p<.01, \eta^{2}=.04\right)$ and "There is no point in doing what I can for climate change unless others do the same." $\left(p<.01, \eta^{2}=.04\right)$. As can be seen in Figure 1, participants rated "high" compared to those rated "low" on egoism agreed mostly on both statements meaning that they perceived less personal control as related to the environmental issues (item $1: M=4.91, S D=1.99$ vs. $M=3.72, S D=1.94$; item 2: $M=4.17$, $S D=2.14$ vs. $M=2.88, S D=1.99$ ).

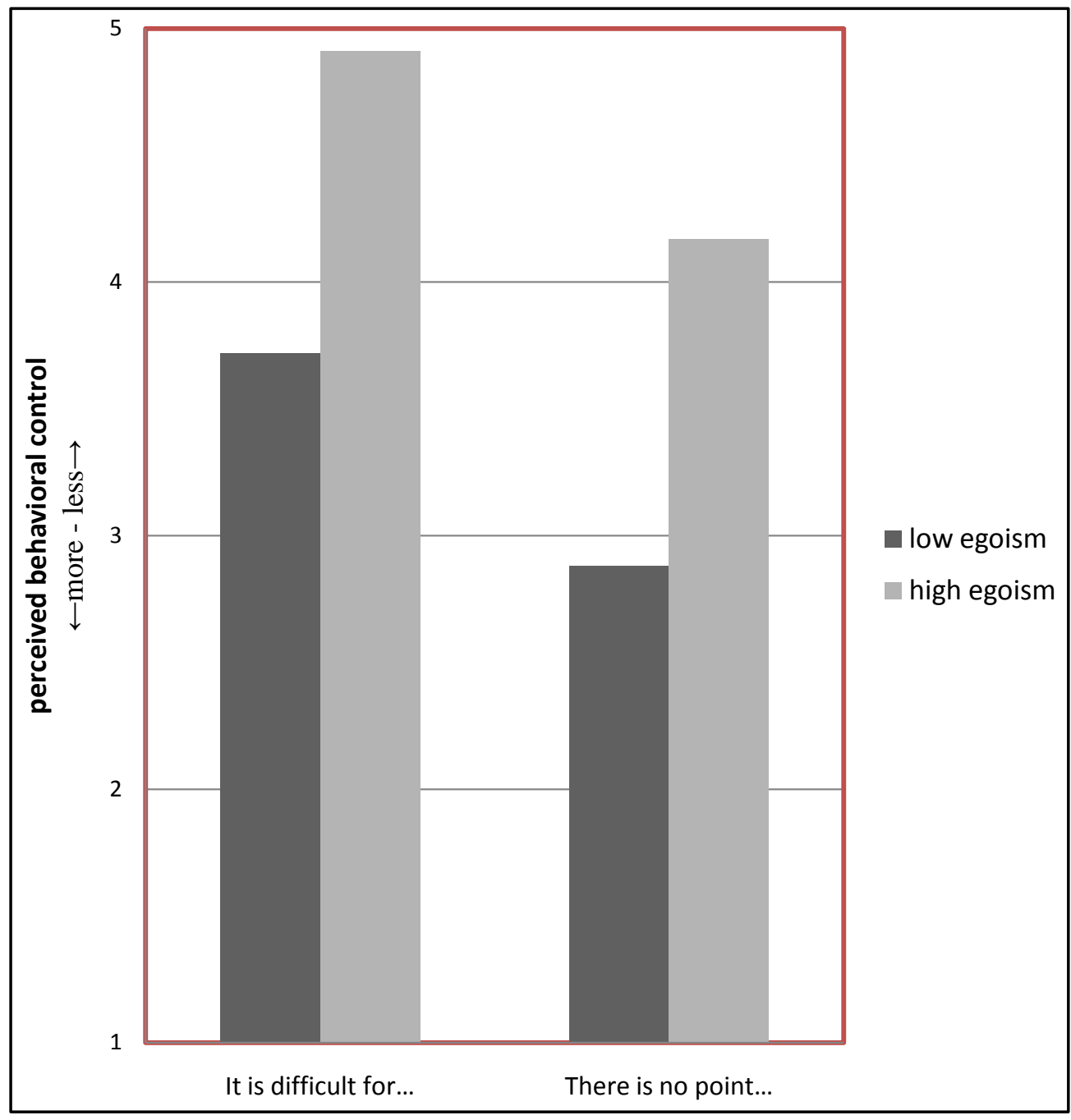

Figure 1. Mean perceived behavioral control in participants estimated to be "low" vs. "high" on Egoism; for items "It is just too difficult for someone like me to do much about the climate change." and "There is no point in doing what I can for the climate change unless others do the same." 
A strong tendency to a main significant effect on willingness to sacrifice was indicated-Wilk's Lambda $=.98$, $F(3,400)=2.24, p=.08, \eta^{2}=.02$-significantly associated with all three items "I am willing to pay much higher taxes to protect the environment." ( $\left.p<.01, \eta^{2}=.02\right)$, "I am willing to pay much higher prices to protect the environment." ( $\left.p<.05, \eta^{2}=.01\right)$ and "I am willing to accept cuts in standard of living to protect the environment." $\left(p<.05, \eta^{2}=.01\right)$. Participants rated "high" on egoism were shown to be less willing to sacrifice than participants rated "low" on egoism did (item 1: $M=3.36, S D=2.99$ vs. $M=4.18, S D=2.04$; item $2: M=3.60, S D=$ 2.23 vs. $M=4.34, S D=1.91$; item 3: $M=3.89, S D=2.29$ vs. $M=4.49, S D=1.88$; see Figure 2).

A main significant effect on action behaviour was obtained-Wilk's Lambda $=.98, F(2,389)=3.54, p<.05$, $\eta^{2}=.02$-associated with question "How often do you cut back on driving a car for environmental reasons?" $\left(p<.05, \eta^{2}=.01\right)$. Participants rated "high" $(M=3.81, S D=1.43)$ compared to those rated "low" $(M=4.13$, $S D=1.16$ ) on egoism were the ones that were less prepared not-to-drive their car for environmental reasons.

A strong tendency to a main significant effect on collective efficacy was indicated-Wilk's Lambda $=.98, F(3$, $398)=2.30, p=.07, \eta^{2}=.02$-associated with statements "I am sure that we can achieve progress, because we are pulling in the same direction." ( $\left.p=.06, \eta^{2}=.01\right)$ and "I am confident that together we can solve the problem of climate change." $\left(p<.02, \eta^{2}=.01\right)$. As can be seen in Figure 3, participants rated "high" on egoism believed more in collective efficacy than participants rated "low" on egoism did (item $1: M=5.0, S D=1.51$ vs. $M=4.43$, $S D=1.57$; item $2: M=4.75, S D=1.73$ vs. $M=4.28, S D=1.58$ ).

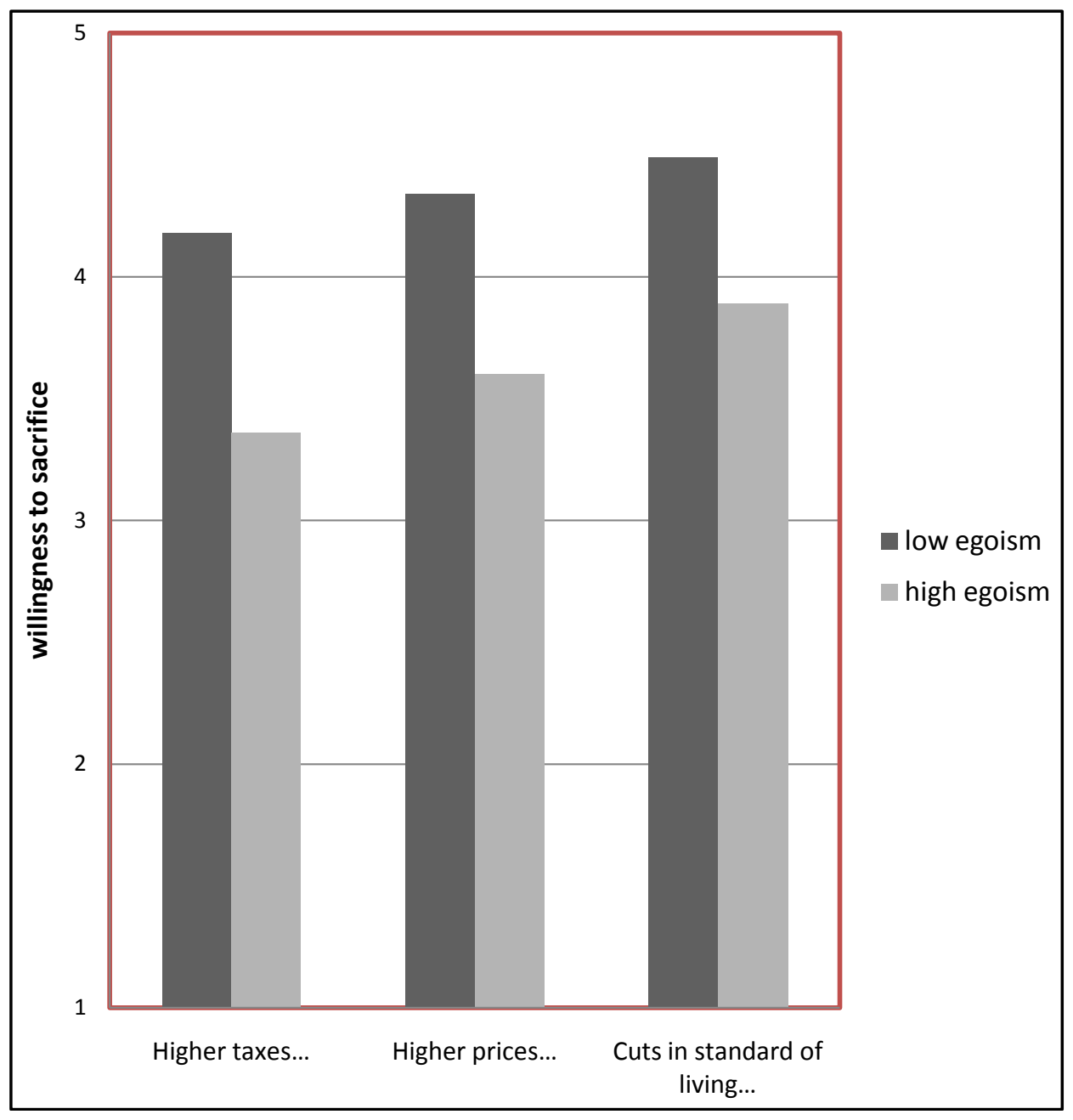

Figure 2. Mean willingness to sacrifice in participants estimated to be "low” vs. "high" on Egoism; for items "I am willing to willing to pay much higher taxes to protect the environment.", "I am willing to pay much higher prices to protect the environment." and "I am willing to accept cuts in standard of living to protect the environment.” 


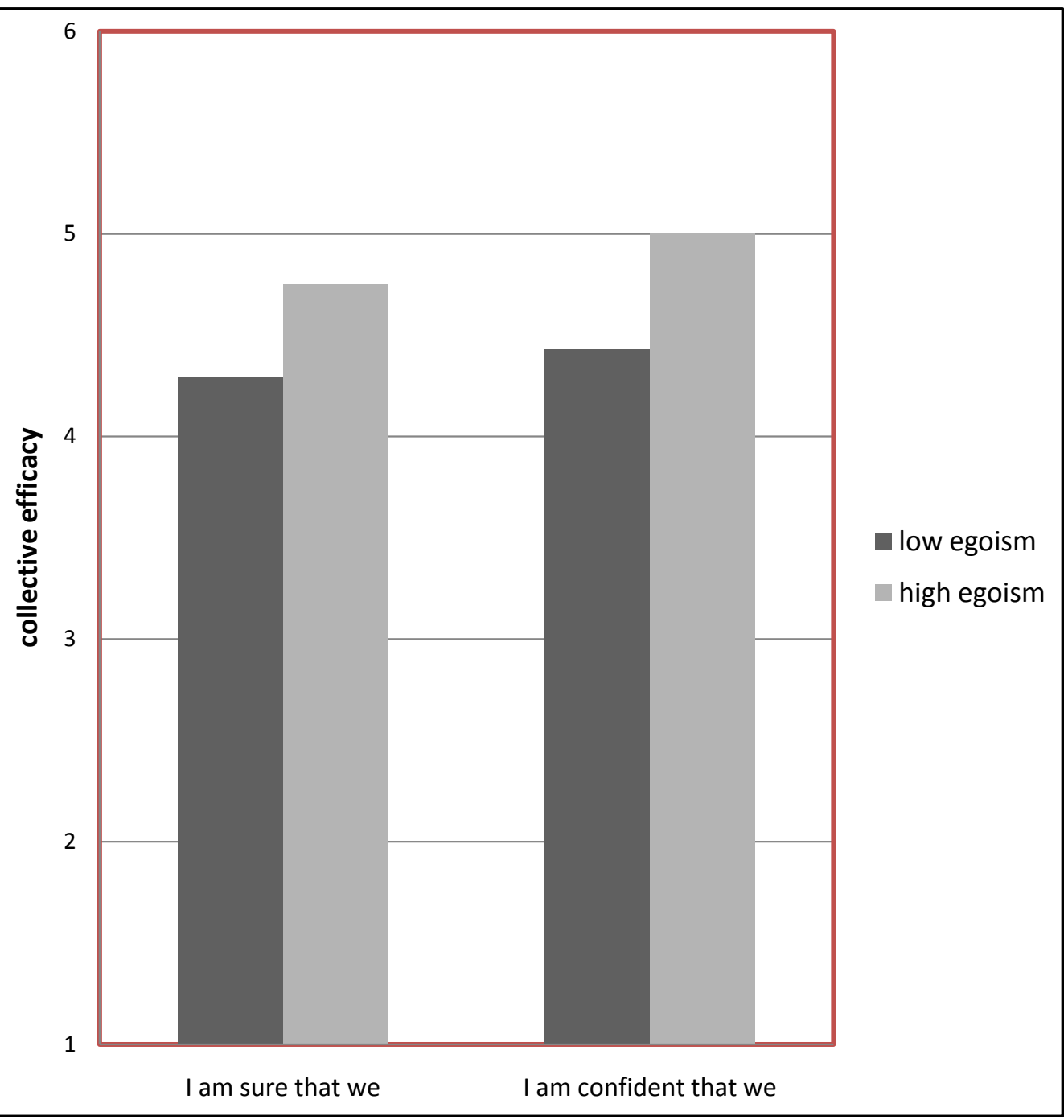

Figure 3. Mean collective efficacy in participants estimated to be "low" vs. "high" on Egoism; for items "I am sure that we can achieve progress, because we are pulling in the same direction." and "I am confident that together we can solve the problem of climate change."

A tendency to a main significant effect on self-efficacy was indicated-Wilk's Lambda $=.98, F(3,392)=2.09$, $p=.10, \eta^{2}=.02$-significantly associated with statement "I don't worry much about climate change consequences because I trust in my ability to cope with them.” $\left(p=.02, \eta^{2}=.02\right)$. Participants rated "high" $(M=4.14$, $S D=2.28$ ) on egoism were shown to be less worried about climate change due to their self-efficacy in coping with that type of environmental problem than participants rated "low" $(M=3.43, S D=1.73)$ on egoism.

\subsection{Effects of Altruism on Pro-Environmental Behaviour}

A MANOVA was performed for each of the five pro-environmental behaviours: "perceived behavioural control" (2 items), "willingness to sacrifice” (3 items), “action behaviour” (2 items), "collective efficacy” (3 items) and "self-efficacy” (3 items).

A main significant effect on perceived behavioural control was obtained-Wilk's Lambda $=.92, F(2,369)=$ $15.39, p<.01, \eta^{2}=.08$. This effect was associated with both items "It is just too difficult for someone like me to do much about climate change." ( $p<.01, \eta^{2}=.04$ ) and (b) "There is no point in doing what I can for climate change unless others do the same." ( $p<.01, \eta^{2}=.07$ ). As can be seen in Figure 4, participants rated "high" compared to those rated "low" on altruism agreed least on both statements meaning that they perceived most 


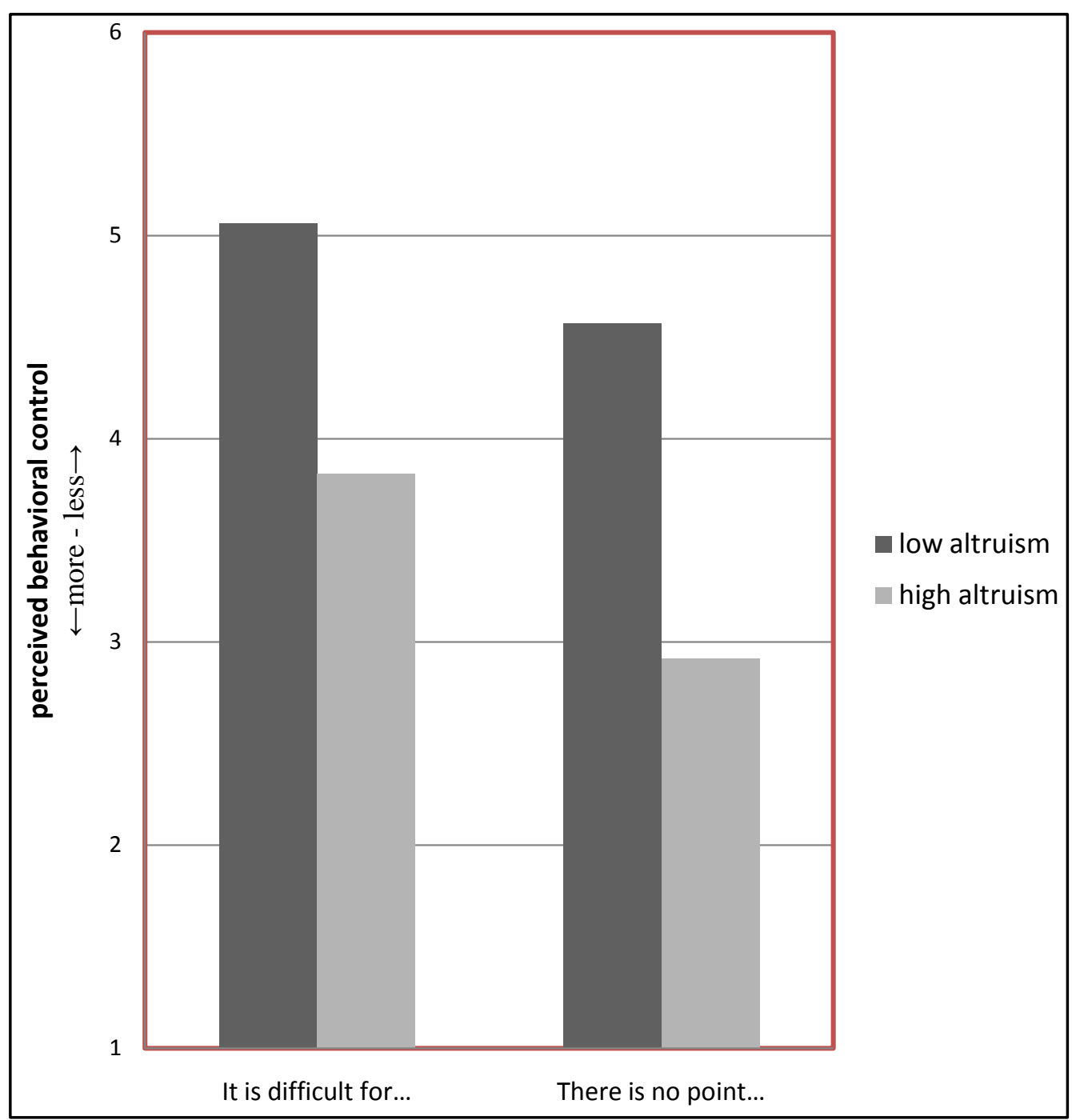

Figure 4. Mean perceived behavioral control in participants estimated to be "low” vs. "high” on Altruism; for items "It is just too difficult for someone like me to do much about the climate change." and "There is no point in doing what I can for the climate change unless others do the same.”

personal control as related to the environmental issues (item $1: M=3.85, S D=1.99$ vs. $M=5.06, S D=2.0$; item 2: $M=2.92, S D=2.0$ vs. $M=4.57, S D=2.33$ ).

A main significant effect on willingness to sacrifice was shown-Wilk's Lambda $=.87, F(3,366)=18.40, p<.01$, $\eta^{2}=.13$-significantly associated with all three items "I am willing to pay much higher taxes to protect the environment." $\left(p<.01, \eta^{2}=.09\right)$, "I am willing to pay much higher prices to protect the environment." $\left(p<.01, \eta^{2}=.08\right)$ and "I am willing to accept cuts in standard of living to protect the environment." $\left(p<.01, \eta^{2}=.12\right)$. Participants rated "high" on altruism were shown to be most willing to sacrifice than participants rated "low" on altruism did (item 1: $M=4.52, S D=2.02$ vs. $M=2.65, S D=2.06$; item $2: M=4.68, S D=1.89$ vs. $M=3.09, S D=1.95$; item 3: $M=4.92, S D=1.75$ vs. $M=3.0, S D=2.13$; see Figure 5).

A main significant effect on action behaviour was obtained-Wilk's Lambda $=.95, F(2,351)=10.11, p<.01$, $\eta^{2}=.05$-associated with both questions "How often do you sort glass, tins, newspaper, etc. for recycling?" $(p<.01$, $\left.\eta^{2}=.02\right)$ and "How often do you cut back on driving a car for environmental reasons?" $\left(p<.01, \eta^{2}=.04\right)$. As can be seen in Figure 6, participants rated "high" compared to those rated "low" on altruism were the ones most ready to recycle and leave the car in the garage for environmental reasons (item $1: M=4.17, S D=1.12$ vs. $M=$ 3.66, $S D=1.49$; item 2: $M=3.66, S D=1.44$ vs. $M=2.78, S D=1.64$ ). 


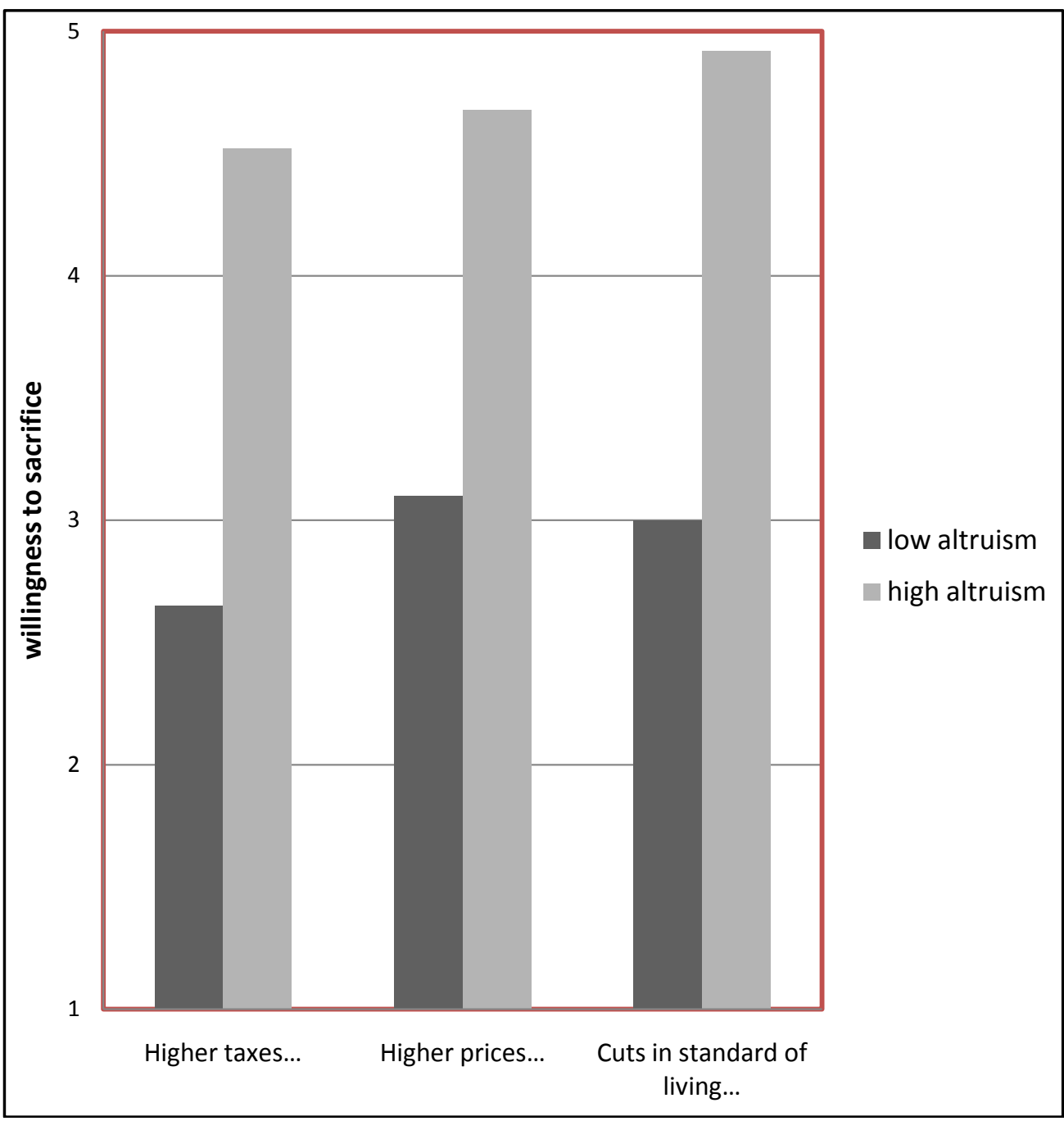

Figure 5. Mean willingness to sacrifice in participants estimated to be "low" vs. "high" on Altruism; for items "I am willing to willing to pay much higher taxes to protect the environment.", "I am willing to pay much higher prices to protect the environment." and "I am willing to accept cuts in standard of living to protect the environment.”

A main significant effect on collective efficacy was obtained-Wilk's Lambda $=.98, \mathrm{~F}(3,363)=2.97, p<.05$, $\eta^{2}=.02$-associated with statement "We can come up with creative ideas to solve climate change problems effectively, even if the external conditions are unfavorable." $\left(p<.01, \eta^{2}=.02\right)$. Participants rated "high" $(M=5.11$, $S D=1.39)$ compared to those rated "low" $(M=4.55, S D=1.97)$ on altruism believed mostly in the collective efficacy of that statement.

A main significant effect on self-efficacy was shown-Wilk's Lambda $=.89, F(3,355)=14.82, p<.01, \eta^{2}=.11$ significantly associated with all three items "Whatever happens in terms of climate change, I will able to handle it." ( $\left.p<.01, \eta^{2}=.04\right)$, "I don't worry much about climate change consequences because I trust in my ability to cope with them." $\left(p<.01, \eta^{2}=.10\right)$ and "I know how to cope with warnings about climate change in everyday life." $\left(p<.01, \eta^{2}=.06\right)$. As can be seen in Figure 7, participants rated "high" on altruism were shown to believe less in their self-efficacy in coping with climate change than participants rated "low" on altruism did (item 1: $M=$ $3.28, S D=1.74$ vs. $M=5.0, S D=1.92$; item $2: M=3.82, S D=1.69$ vs. $M=5.06, S D=1.73$ ).

\section{Discussion}

Do environment-related value orientations of egoism vs. altruism affect pro-environmental behaviour? The 


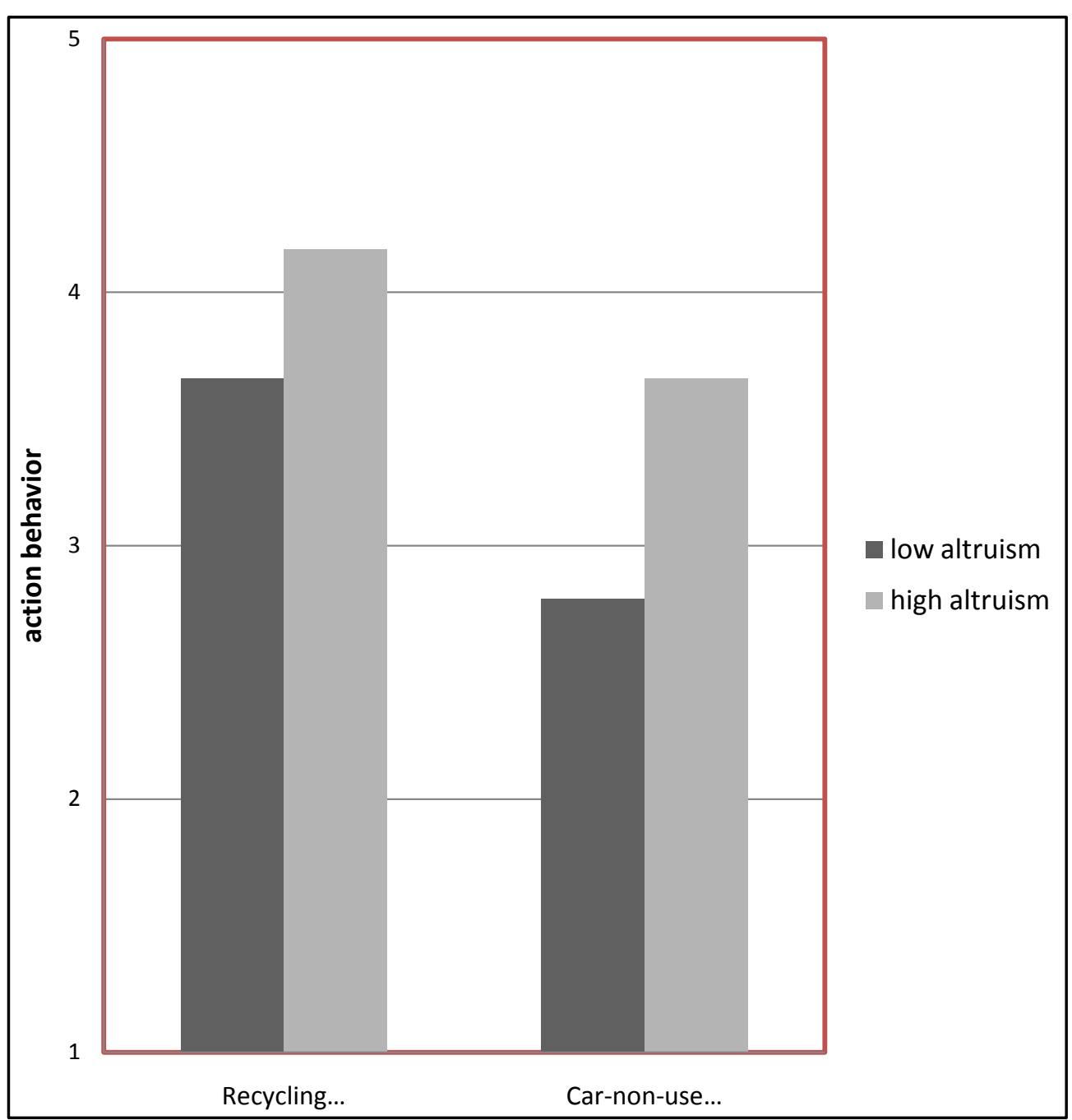

Figure 6. Mean action behavior in participants estimated to be "low" vs. "high” on Altruism; for items "How often do you sort glass, tins, newspaper, etc for recycling?" and "How often do you cut back on driving a car for environmental reasons?”

results obtained show the answer to be "yes".

More precisely, and concerning behavioural intention (behavioural control and willingness to sacrifice), egoistic individuals (rated "high" on egoism) were shown to perceive less control, meaning that they believed that it is too difficult and that there is no point in doing much about environmental issues. They were also less willing to sacrifice; that is, less willing to pay higher taxes and prices as well as cut their standard of living for environmental protection. In contrast, altruistic individuals (rated "high" on altruism) were shown to perceive more control and were more willing to sacrifice. These results support Hypotheses 1 (a, b) and 2 (a, b), implying a self-benefit goal (Batson, 1995) vs. empathy-altruistic goal (Batson, 1991, 1998) in egoistic and altruistic individuals respectively. This is also shown in action behaviour results, showing egoistic compared with altruistic individuals to be less prepared not to drive the car for environmental reasons.

According to the theory of reasoned action (Fishbein \& Ajzen, 1975; Ajzen \& Fishbein, 1980), behavioural intention is "a result of a decision process based on" (Staats, 2003: p. 174) attitude (beliefs about outcomes + evaluations of outcomes) and subjective norm (normative beliefs + motivation to comply). Given this, the results obtained indicate that goals of self-benefit (egoism) vs. others-benefit (altruism) may polarize the decision processing of behavioural intention and action.

As suggested by the theory of planned behaviour (which is an extension of the theory of reason action—see 


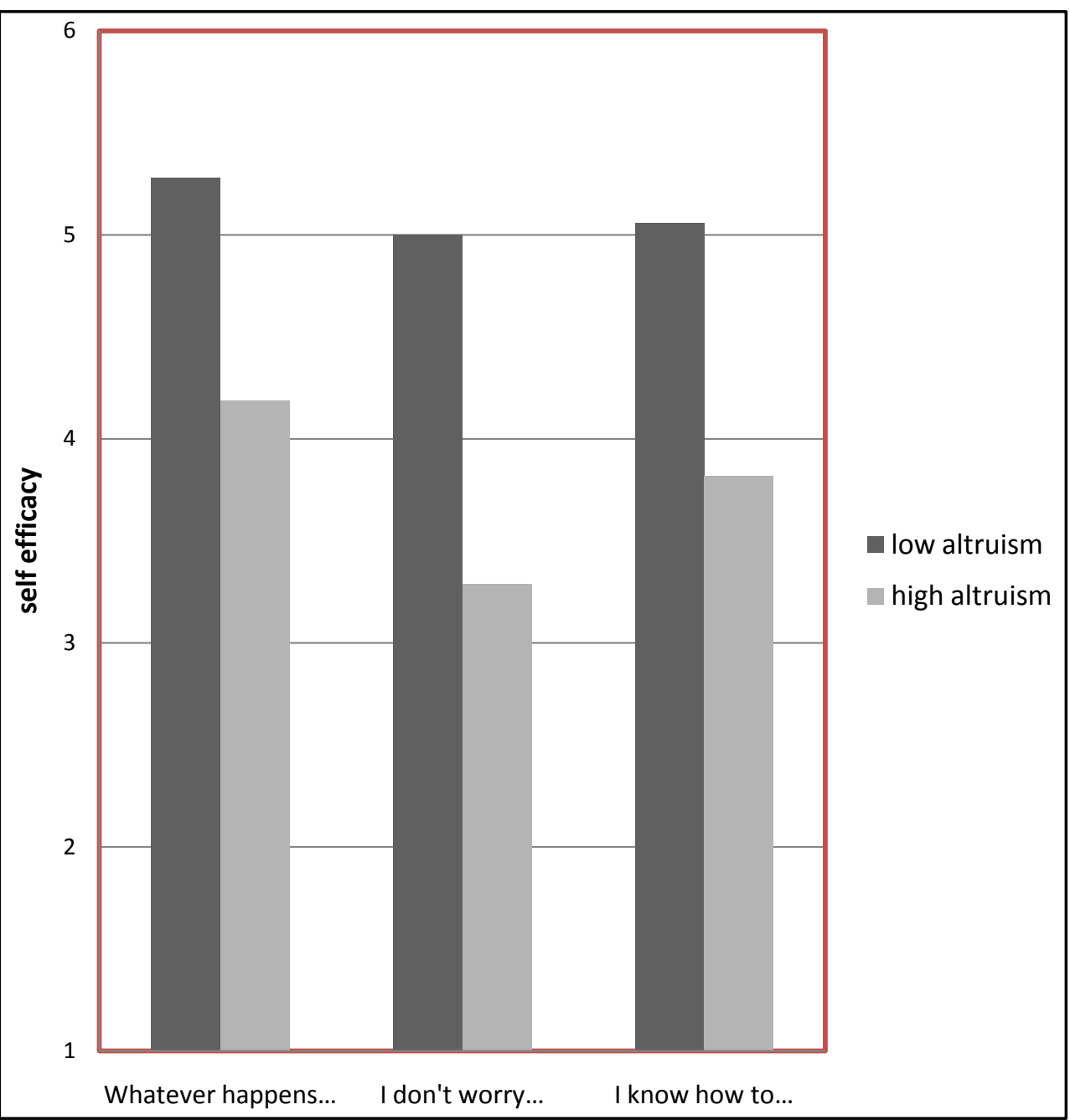

Figure 7. Mean self-efficacy in participants estimated to be "low" vs. "high" on Altruism; for items "Whatever happens in terms of climate change, I will able to handle it.", "I don't worry much about climate change because I trust in my ability to cope with them." and "I know how to cope warnings about climate change in everyday life.”

Ajzen, 1991), behavioural intention may be additionally influenced by behavioural control. This means (and as reported) that low (egoists) compared to high (altruists) control individuals may believe that: "I'm not capable of behaving pro-environmentally.”; "(Un) expected barriers may prevent me from acting pro-environmentally." and "Acting pro-environmentally requires time and skills." Why? Because perceived control is a product of control beliefs and perceived power (see Staats, 2003 for a review).

Regarding resource appraisal (collective and self-efficacy), and in line with Hypotheses 1 (d, e) and 2 (d, e), both egoistic and altruistic individuals believed in collective efficacy (" ...that together we can solve the problem of climate change”). However, the former believed more in self-efficacy (“...I trust in my ability to cope with climate change consequences"). Thus, and according to the phenomenon of "unintended consequences" (Batson et al., 2003), egoistic individuals also believed in collective efficacy as a means of benefiting themselves in the long run (see also Cialdini et al., 1997; Maner et al., 2002).

Given that “...the ultimate goal is the self-benefit of having one's own discomfort go away” (Batson et al., 2003: p. 284), this result may also indicate a reduction in aversive arousal in egoistic individuals with regard to others' suffering upsetting the egoistic self. In addition, and corresponding to the self-benefit goal hypothesis (Batson, 1995), egoistic individuals assessed themselves to be self-efficient. In contrast and along the lines of the empathy-altruism hypothesis (Batson, 1991, 1998), altruistic individuals believed most in collective (...we 
can solve the problem) but least in self-efficacy (...I can solve the problem). This is also in accord with some previous findings indicating that a problem-solution-focused coping (i.e. type of a reduction of uncertainty and complexity-e.g. Bachrach \& Zautra, 1985; Iwata, 2002), operationalized as collective and self-efficacy (Homburg \& Stolberg, 2006), may influence pro-environmental behaviour.

In sum, the climate-change-related value orientations of egoism and altruism were shown to significantly affect pro-environmental behaviour thus indicating a phenomenon of environmental ethics (Fogg, 2000; Ehrich, 2002; Kaiser, 2006; Karpiak \& Baril, 2008). This suggests that environment-related moral imperatives may initiate a lesser or greater willingness toward pro-environmental actions (see Steg \& Vlek, 2009 for a review). In spite of this, can we conclude that climate change is a moral issue (Markowitz, 2012)? Is it clear to everyone that one should behavepro-environmentally for the sake of the planet? If so, a moral proposition entailing proenvironmental behaviour ought to comprise three components (Hare, 1981): 1) Universal (the pro-environmental imperative applies to everyone); 2) Prescriptive (the pro-environmental imperative tells us what to do or what not to do) and 3) Evaluative (the pro-environmental imperative tells what is right and wrong).

Given the results obtained in this study and in Knez (2013), it is clear that a deontic proposition of "we should behave pro-environmentally" is recognized as a moral issue by the altruistic individuals but not by the egoistic ones. It would appear that the latter identified this requirement as a matter of opinion and, therefore, something that they do not need to be a devotee of, or as a denial that protects "from anxiety about global environmental and social problems" (Sparks, Jessop, Chapman, \& Holmes, 2010: p. 554; see also Opotow \& Weiss, 2000). Alternatively, in terms of Schroeder et al. (2010), we may consider egoists as motivational instrumentalists (moral action stems from one's own wants) and altruists as motivational personalists (moral action stems from one's knowledge ("good character") of what is right) thereby indicating instrumental vs. intrinsic values (Light \& Katz, 1996; Leopold, 1949/1987) in egoists and altruists respectively.

\section{Conclusion}

Environment problems caused by human behaviour (Nickerson, 2003) are a central issue on the international political agenda (IPCC, 2007). In order to improve both local and international policy issues, it is important to understand mechanisms grounding such destructive deeds. Therefore, when promoting sustainable policy, we must take into account peoples' values because they are guiding behavioural principles in our lives (Schwartz, 1992). For that reason, we may conceptualize environment-related selfishness (climate change is not a moral issue) and unselfishness (climate change issue is a moral issue) as imperatives framing (Nisbet, 2009; Aitken et al., 2011) behaviours that "drive" (Stern, 2011) climate change. This indicates that morality may regulate climatechange-related behaviours (Steg \& Vlek, 2009), meaning that we have to learn which issues are moral and which are not (Bucciarelli et al., 2008) in order to promote "ethical" decision making (Jones, 1991; Hershfield, Cohen, \& Thompson, 2012). One pedagogical method that may be useful to implement is the "moral circle" (Singer, 1981). It has been shown to enhance and promote pro-sociality (Reed \& Aquino, 2003; Laham, 2009) and pro-environmentalism (Bratanova, Luoghnan, \& Gatersleben, 2012), as well as to identify strategies for enhancing the "moral intuitions" about climate change (Markowitz \& Shariff, 2012).

\section{References}

Aitken, C., Chapman, R., \& McClure, J. (2011). Climate Change, Powerlessness and the Commons Dilemma: Assessing New Zealanders' Preparedness to Act. Global Environmental Change, 21, 752-760.

Ajzen, I. (1991). The Theory of Planned Behavior. Organizational behavior and human decision processes, 50, $179-211$.

Ajzen, I., \& Fishbein, M. (1980). Understanding Attitudes and Predicting Social Behavior. Englewood Cliffs, NJ: PrenticeHall.

Bachrach, K. M., \&Zautra, A. J. (1985). Coping with a Community Stressor: The Threat of a Hazardous Waste Facility. Journal of Health and Social Behavior, 26, 127-141.

Bandura, A. (1997). Self-Efficacy: The Expertise of Control. New York: Freemann.

Batson, C. D. (1991). The Altruism Question: Toward a Social Psychological Answer. Hillsdale, NJ: Erlbaum.

Batson, C. D. (1995). Prosocial Motivation: Why Do We Help Others? In A. Tesser (Ed.), Advanced Social Psychology (pp. 333-381). New York: McGraw-Hill.

Batson, C. D. (1998). Altruism and Prosocial Behavior. In D. T. Gilbert, S. T. Fiske, \& G. Lindzey (Eds.), The Handbook of Social Psychology (4th ed., Vol. 2, pp. 282-316). Boston, MA: McGraw-Hill. 
Batson, C. D. (2011). Altruism in Humans. New York: Oxford University Press.

Batson, C. D., Van Lange, P. A. M., Ahmad, N., \& Lishner, D. A. (2003). Altruism and Helping Behavior. In M. A. Hogg, \& J. Cooper (Eds.), The SAGE Handbook of Social Psychology (pp. 279-295). London: SAGE Publications.

Biel, A., \& Thögerson, J. (2007). Activation of Social Norms in Social Dilemmas: A Review of the Evidence and Reflections on the Implications for Environmental Behavior. Journal of Economic Psychology, 28, 93-112.

Boehnke, K., Fuss, D., \& Rupf, M. (2001). Values and Well-Being: The Mediating Roles of Worries. In P. Schmuck, \& K. M. Sheldon (Eds.), Life-Goals and Wellbeing: Towards a Positive Psychology of Human Striving (pp. 85-101). Seattle: Hogrefe \& Huber Publishers.

Böhm, G., \& Pfister, H.-R. (2001). Mental Representations of Global Environmental Risks. Research in Social Problems and Public Policy, 9, 1-30.

Bonnes, M., \& Bonaiuto, M. (2002). Environmental Psychology: From Spatial-Physical Environment to Sustainable Development. In R. B. Bechtel, \& A. Churchman (Eds.), Handbook of Environmental Psychology (pp. 28-54). New York: John Wiley \& Sons.

Bratanova, B., Loughnan, S., \& Gatersleben, B. (2012). The Moral Circle as a Common Motivational Cause of Cross-Situational Pro-Environmentalism. European Journal of Social Psychology, 42, 539-545.

Broome, J. (2008). The Ethics of Climate Change. Scientific American, 298, 96-102. http://dx.doi.org/10.1038/scientificamerican0608-96

Bucciarelli, M., Khemlani, S., \& Johnson-Laurd, P. N. (2008). The Psychology of Moral Reasoning. Judgment and Decision Making, 3, 121-139.

Cialdini, R. B., Brown, S. L., Lewis, B. P., Luce, C., \& Neuberg, S. L. (1997). Reinterpreting the Empathy-Altruism Relationship: When One into One Equals Oneness. Journal of Personality and Social Psychology, 73, 481-494. http://dx.doi.org/10.1037/0022-3514.73.3.481

Corner, A., \& Hahn, U. (2012). Evaluating Science Arguments: Evidence, Uncertainty, and Argument Strength. Journal of Experimental Psychology: Applied, 15, 199-212. http://dx.doi.org/10.1037/a0016533

Corral-Verdugo, V., Bechtel, R. B., \& Fraijo-Sing, B. (2003). Environmental Beliefs and Water Conservation: An Empirical Study. Journal of Environmental Psychology, 23, 247-257. http://dx.doi.org/10.1016/S0272-4944(02)00086-5

Davidson, M. D. (2008). Wrongful Harm to Future Generations: The Case of Climate Change. Environmental Values, 17, 471-488. http://dx.doi.org/10.3197/096327108X368494

DeCoster, J., Iselin, A.-M. R., \& Galluci, M. (2009). A Conceptual and Empirical Examination of Justifications for Dichotomization. Psychological Methods, 14, 349-366. http://dx.doi.org/10.1037/a0016956

Di Castri, F. (2000). Ecology in Context of Economic Globalization. BioScience, 50, 321-332. http://dx.doi.org/10.1641/0006-3568(2000)050[0321:EIACOE]2.3.CO;2

Dutt, V., \& Gonzalez, C. (2012). Why Do We Want to Delay Actions on Climate Change? Effects of Probability and Timing of Climate Change. Journal of Behavioral Decision Making, 25, 154-164. http://dx.doi.org/10.1002/bdm.721

Ehrich, P. R. (2002). Human Natures, Nature Conservation, and Environmental Ethics: Cultural Evolution Is Required, in Both the Scientific Community and the Public at Large, to Improve Significantly the Now Inadequate Response of Society to the Human Predicament. BioScience, 52, 31-43. http://dx.doi.org/10.1641/0006-3568(2002)052[0031:HNNCAE]2.0.CO;2

Elster, J. (2005). Fehr on Altruism, Emotion, and Norms. Analyse \& Kritik, 27, 198-211. http://dx.doi.org/10.1515/auk-2005-0112

Fehr, E., \& Fischbacher, U. (2003). The Nature of Human Altruism. Nature, 425, 785-791. http://dx.doi.org/10.1038/nature02043

Fishbein, M., \& Ajzen, I. (1975). Belief, Attitude, Intention, and Behavior. Reading, MA: Addison-Wesley.

Fogg, M. J. (2000). The Ethical Dimensions of Space Settlement. Space Policy, 16, 205-211. http://dx.doi.org/10.1016/S0265-9646(00)00024-2

Garcia-Mira, R., Real, J. E., \& Romay, J. (2005). Temporal and Spatial Dimensions in the Perception of Environmental Problems: An Investigation of the Concept of Environmental Hyperopia. International Journal of Psychology, 40, 5-10. http://dx.doi.org/10.1080/00207590444000078

Gardner, G. T., \& Stern, P. C. (1996). Environmental Problems and Human Behavior. Boston, MA: Allyn \& Bacon.

Hansla, A., Gamble, A., Juliusson, A., \& Gärling, T. (2008). The Relationships between Awareness of Consequences, Environmental Concern, and Value Orientations. Journal of Environmental Psychology, 28, 1-9. http://dx.doi.org/10.1016/j.jenvp.2007.08.004

Hardin, G. (1968). The Tragedy of the Commons. Science, 162, 1243-1248. http://dx.doi.org/10.1126/science.162.3859.1243 
Hardy, C. L., \& van Vugt, M. (2006). Nice Guys Finish First: The Competitive Altruism Hypothesis. Personality and Social Psychology Bulletin, 32, 1402-1423. http://dx.doi.org/10.1177/0146167206291006

Hare, R. M. (1981). Moral Thinking: Its Levels, Method and Point. Oxford: Clarendon Press. http://dx.doi.org/10.1093/0198246609.001.0001

Hatcher, T. (2004). Environmental Ethics as an Alternative for Evaluation Theory in For-Profit Business Context. Evaluation and Program Planning, 27, 357-363. http://dx.doi.org/10.1016/j.evalprogplan.2004.04.009

Henry J. Kaiser Family Foundation (2000). Election Values Survey. Washington Post, 7-17 September 2000.

Hershfield, H. E., Cohen, T. R., \& Thompson, L. (2012). Short Horizons and Tempting Situations: Lack of Continuity to Our Future Selves Leads to Unethical Decision Making and Behavior. Organizational Behavior and Human Decision Processes, 117, 298-310. http://dx.doi.org/10.1016/j.obhdp.2011.11.002

Homburg, A., \& Stolberg, A. (2006). Explaining Pro-Environmental Behavior with a Cognitive Theory of Stress. Journal of Environmental Psychology, 26, 1-14. http://dx.doi.org/10.1016/j.jenvp.2006.03.003

Intergovernmental Panel on Climate Change (IPCC) (2007). Climate Change 2007: The Physical Science Basis. Summary for Policy Makers. Geneva: IPCC.

IPCC (2007). AR4 Synthesis Report, Full Report. Intergovernmental Panel on Climate Change. http://www.ipcc.ch/pdf/assessment-report/ar4/syr/ar4_syr.pdf

Iwata, O. (2002). Coping Style and Three Psychological Measures Associated with Environmentally Responsible Behavior. Social Behavior and Personality, 30, 661-669. http://dx.doi.org/10.2224/sbp.2002.30.7.661

Jamieson, D. (2009). Climate Change, Responsibility, and Justice. Science and Engineering Ethics, 16, 431-445. http://dx.doi.org/10.1007/s11948-009-9174-x

Jones, T. M. (1991). Ethical Decision Making by Individuals in Organizations: An Issue-Contingent Model. The Academy of Management Review, 16, 366-395.

Kaiser, F. G. (1998). A General Measure of Ecological Behavior. Journal of Applied Social Psychology, 28, 395-422. http://dx.doi.org/10.1111/j.1559-1816.1998.tb01712.x

Kaiser, F. G. (2006). A Moral Extension of the Theory of Planned Behavior: Norms and Anticipated Feelings of Regret in Conservationism. Personality and Individual Differences, 41, 71-81. http://dx.doi.org/10.1016/j.paid.2005.11.028

Kaiser, F. G., Schultz, P. W., Berenguer, J., Corral-Verdugo, V., \& Tankha, G. (2008). Extending Planned Environmentalism: Anticipated Guilt and Embarrassment across Cultures. European Psychologist, 13, 288-297. http://dx.doi.org/10.1027/1016-9040.13.4.288

Karpiak, C. P., \& Baril, G. L. (2008). Moral Reasoning and Concern for the Environment. Journal of Environmental Psychology, 28, 203-208. http://dx.doi.org/10.1016/j.jenvp.2007.12.001

Knez, I. (2005). Attachment and Identity as Related to a Place and Its Perceived Climate. Journal of Environmental Psychology, 25, 207-218. http://dx.doi.org/10.1016/j.jenvp.2005.03.003

Knez, I. (2013). How Concerned, Afraid and Hopeful Are We? Effects of Egoism and Altruism on Climate Change Related Issues. Psychology, 4, 744-752. http://dx.doi.org/10.4236/psych.2013.410106

Knez, I., \& Thorsson, S. (2006). Influences of Culture and Environmental Attitude on Thermal, Emotional and Perceptual Evaluations of a Square. International Journal of Biometeorology, 50, 258-268. http://dx.doi.org/10.1007/s00484-006-0024-0

Knez, I., Thorsson, S., \& Eliasson, I. (2013). Climate Change: Concerns, Beliefs and Emotions in Residents, Experts, Decision Makers, Tourists, and Tourist Industry. American Journal of Climate Change, 2, 254-269. http://dx.doi.org/10.4236/ajcc.2013.24025

Koppe, C. G., Kovats, S., Jendritzky, G., \& Menne, B. (2004). Heat Waves: Risks and Responses. Copenhagen: World Health Organization.

Kortenkamp, K. V., \& Moore, C. F. (2006). Time, Uncertainty, and Individual Differences in Decisions to Cooperate in Resource Dilemmas. Personality and Social Psychology Bulletin, 32, 603-615. http://dx.doi.org/10.1177/0146167205284006

Laham, S. (2009). Expanding the Moral Circle: Inclusion and Exclusion Mindsets and the Circle of Moral Regard. Journal of Experimental Social Psychology, 45, 250-253. http://dx.doi.org/10.1016/j.jesp.2008.08.012

Lazarus, R. S. (1966). Psychological Stress and the Coping Process. New York: McGraw-Hill.

Lazarus, R. S. (1991). Emotion and Adaption. Oxford: Oxford University Press.

Leiserowitz, A. (2006). Climate Change Risk Perception and Policy Preferences: The Role of Affect, Imagery, and Values. Climatic Change, 77, 45-72. http://dx.doi.org/10.1007/s10584-006-9059-9

Leopold, A. (1949/1987). A Sand County Almanac and Sketches Here and There. New York: Oxford University Press.

Lepore, S., \& Evans, G. (1996). Coping with Multiple Stressors in the Environment. In M. Zeidenr, \& N. S. Endler (Eds.), 
Handbook of Coping: Theory, Research, Applications (pp. 350-377). New York: Wiley.

Lewin, K. (1951). Field Theory in Social Science. New York: Harper.

Liebert, R. M., \& Liebert, L. L. (1995). Science and Behavior: An Introduction to Methods of Psychological Research. New York: Prentice Hall.

Light, A., \& Katz, E. (1996). Environmental Pragmatism. London: Routledge.

Loewenstein, G. F., Weber, E. U., Hsee, C. K., \& Welch, N. (2001). Risk as Feelings. Psychological Bulletin, 127, $267-286$. http://dx.doi.org/10.1037/0033-2909.127.2.267

Maner, J. K., Luce, C. L., Neuberg, S. L., Cialdini, R. B., Brown, S., \& Sagarin, B. J. (2002). The Effects of Perspective Taking on Motivations for Helping: Still No Evidence for Altruism. Personality and Social Psychology Bulletin, 28, 16011610. http://dx.doi.org/10.1177/014616702237586

Markowitz, E. M. (2012). Is Climate Change an Ethical Issue? Examining Young Adult's Beliefs about Climate and Morality. Climatic Change, 114, 479-495. http://dx.doi.org/10.1007/s10584-012-0422-8

Markowitz, E. M., \& Shariff, A. F. (2012). Climate Change and Moral Judgement. Nature Climate Change, 2, $243-247$. http://dx.doi.org/10.1038/nclimate1378

Marx, S. M., Weber, E. U., Orlove, B. S., Leiserowitz, A., Krantz, D. H., Roncoli, C., \& Phillips, J. (2007). Communication and Mental Processes: Experiential and Analytic Processing of Uncertain Climate Information. Global Environmental Change, 17, 47-58. http://dx.doi.org/10.1016/j.gloenvcha.2006.10.004

McGuigan, F. J. (1983). Experimental Psychology: Methods of Research. Upper Saddle River, NJ: Prentice Hall, Inc.

Menzel, S., \& Bögeholz, S. (2010). Values, Beliefs and Norms That Foster Chilean and German Pupils' Commitment to Protect Biodiversity. International Journal of Environmental \& Science Education, 5, 31-49.

Miller, D. T. (1999). The Norm of Self-Interest. American Psychologist, 54, 1053-1060. http://dx.doi.org/10.1037/0003-066X.54.12.1053

Nickerson, R. S. (2003). Psychology and Environmental Change. London: Lawrence Erlbaum Associates.

Nisbet, M. C. (2009). Communicating Climate Change: Why Frames Matter for Public Engagement. Environment: Science and Policy for Sustainable Development, 51, 12-23. http://dx.doi.org/10.3200/envt.51.2.12-23

Nordlund, A., \& Garvill, J. (2003). Effects of Values, Problem Awareness, and Personal Norms on Willingness to Reduce Personal Car Use. Journal of Environmental Psychology, 23, 339-347. http://dx.doi.org/10.1016/S0272-4944(03)00037-9

Ojala, M. (2007). Hope and Worry: Exploring Young People's Values, Emotions, and Behaviour Regarding Global Environmental Problems. Doctoral Dissertation, Örebro: Örebro University.

Olofsson, A., \& Öhman, S. (2006). General Beliefs and Environmental Concern: Transantlantic Comparisons. Environment and Behavior, 38, 768-790. http://dx.doi.org/10.1177/0013916506287388

Opotow, S., \& Weiss, L. (2000). Denial and the Process of Moral Exclusion in Environmental Conflict. Journal of Social Issues, 56, 475-490. http://dx.doi.org/10.1111/0022-4537.00179

Oreg, S., \& Katz-Gerro, T. (2006). Predicting Proenvironmental Behavior Cross-Nationally: Values, the Theory of Planned Behavior, and Value-Belief-Norm Theory. Environment and Behavior, 38, 462-483. http://dx.doi.org/10.1177/0013916505286012

Pelletier, L. G., Lavergne, K. J., \& Sharp, E. C. (2008). Environmental Psychology and Sustainability: Comments on Topics Important for Our Future. Canadian Psychology, 49, 304-308. http://dx.doi.org/10.1037/a0013658

Reed, A., \& Aquino, K. F. (2003). Moral Identity and the Expanding Circle of Moral Regard towards Out-Groups. Journal of Personality and Social Psychology, 84, 1270-1286. http://dx.doi.org/10.1037/0022-3514.84.6.1270

Rushton, J. P., \& Sorrentino, R. M. (Eds.) (1981). Altruism and Helping Behavior: Social, Personality, and Developmental Perspectives. Hillsdale, NJ: Lawrence Erlbaum Associates, Publishers.

Saad, L. (2002). American Sharply Divided on Seriousness of Global Warming. Gallup Poll Monthly (Report No. 438, pp. 43-48). Princeton, NJ: Gallup.

Sage, A. (1992). Systems Engineering. New York: Wiley.

Scherbaum, C., Popovich, P., \& Finlinson, S. (2008). Exploring Individual-Level Factors Related to Employee Energy Conservation Behaviors at Work. Journal of Applied Social Psychology, 38, 818-835. http://dx.doi.org/10.1111/j.1559-1816.2007.00328.x

Schmuck, P., \& Vlek, C. (2003). Psychologists Can Do Much to Support Sustainable Development. European Psychologist, 8, 66-76. http://dx.doi.org/10.1027//1016-9040.8.2.66

Schroeder, D. A., Penner, L. A., Dovidio, J. F., \& Piliavin, J. A. (1995). The Psychology of Helping and Altruism: Problems and Puzzles. New York: McGraw-Hill. 
Schroeder, T., Roskies, A., \& Nichols, S. (2010). Moral Motivation. In J. M. Doris, \& The Moral Psychology Research Group (Eds.), The Moral Psychology Handbook (pp. 72-110). New York: Oxford University Press. http://dx.doi.org/10.1093/acprof:oso/9780199582143.003.0004

Schultz, P. W. (2001). The Structure of Environmental Concern: Concern for Self, Other People, and the Biosphere. Journal of Environmental Psychology, 21, 327-339. http://dx.doi.org/10.1006/jevp.2001.0227

Schultz, P. W., Gouveia, V. V., Cameron, L. D., Tankha, G., Schmuck P., \& Franek, M. (2005). Values and Their Relationship to Environmental Concern and Conservation Behavior. Journal of Cross-Cultural Psychology, 36, 457-475. http://dx.doi.org/10.1177/0022022105275962

Schwartz, S. H. (1970). Moral Decision Making and Behavior. In M. Macauley, \& L. Berkowitz (Eds.), Altruism and Helping Behavior (pp. 127-141). New York: Academic Press.

Schwartz, S. H. (1977). Normative Influence on Altruism. In L. Berkowitz (Ed.), Advances in Experimental Social Psychology (Vol. 10, pp. 221-279). New York: Academic Press. http://dx.doi.org/10.1016/s0065-2601(08)60358-5

Schwartz, S. H. (1992). Universals in the Content and Structure of Values: Theoretical Advances and Empirical Tests in 20 Countries. In M. Zanna (Ed.), Advances in Experimental Psychology (Vol. 25, pp. 1-65). Orlando, FL: Academic Press. http://dx.doi.org/10.1016/s0065-2601(08)60281-6

Schwartz, S. H. (1994). Are There Universal Aspects in the Structure and Contents of Human Values? Journal of Social Issues, 50, 19-45. http://dx.doi.org/10.1111/j.1540-4560.1994.tb01196.x

Scott, D., de Freitas, C. R., \& Matzarakis, A. (2009). Adaptation in the Tourism and Recreation Sector. In K. L. Ebi, G. Burton, I., \& G. R. McGregor (Eds.), Biometeorology for Adaptation to Climate Variability and Change (pp. 171-194). Netherlands: Springer. http://dx.doi.org/10.1007/978-1-4020-8921-3_8

Scott, D., Peeters, P., \& Gössling, S. (2010). Can Tourism Deliver Its “Aspirational” Greenhouse Gas Emission Reduction Targets? Journal of Sustainable Tourism, 18, 393-408. http://dx.doi.org/10.1080/09669581003653542

Singer, P. (1981). The Expanding Circle: Ethics and Sociobiology. Oxford: Oxford University Press.

Slovic, P., Finucane, M. L., Peters, E., \& MacGregor, D. G. (2002). The Affect Heuristic. In T. Gilovich, D. Griffin, \& D. Kahneman (Eds.), Heuristics and Biases: The Psychology of Intuitive Judgment (pp. 397-420). New York: Cambridge University Press. http://dx.doi.org/10.1017/cbo9780511808098.025

Sober, E., \& Wilson, D. S. (1998). Unto Others: The Evolution and Psychology of Unselfish Behavior. Cambridge, MA: Harvard University Press.

Sparks, P., Jessop, D. C., Chapman, J., \& Holmes, K. (2010). Pro-Environmental Actions, Climate Change, and Defensiveness: Do Self-Affirmations Make a Difference to People’s Motives and Beliefs about Making a Difference? British Journal of Social Psychology, 49, 553-568. http://dx.doi.org/10.1348/014466609X471976

Staats, H. (2003). Understanding Proenvironmental Attitudes and Behavior: An Analysis and Review of Research Based on Theory of Planned Behavior. In M. Bonnes, T. Lee, \& M. Bonaiuto (Eds.), Psychological Theories for Environmental Issues (pp. 171-201). Burlington, VT: Ashgate.

Steg, L., \& Vlek, C. (2009). Encouraging Pro-Environmental Behavior: An Integrative Review and Research Agenda. Journal of Environmental Psychology, 29, 309-317. http://dx.doi.org/10.1016/j.jenvp.2008.10.004

Stern, N. (2006). The Economics of Climate Change: The Stern Review. Cambridge: Cambridge University Press.

Stern, P. C. (2000a). Psychology and the Science of Human-Environment Interactions. American Psychologists, 55, 523-550. http://dx.doi.org/10.1037/0003-066X.55.5.523

Stern, P. C. (2000b). New Environmental Theories: Toward a Coherent Theory of Environmentally Significant Behavior. Journal of Social Issues, 56, 407-424. http://dx.doi.org/10.1111/0022-4537.00175

Stern, P. C. (2011). Contributions of Psychology to Limiting Climate Change. American Psychologist, 66, 303-314. http://dx.doi.org/10.1037/a0023235

Stich, S. P., Doris, J. M., and Roedder, E. (2010). Altruism. In J.M. Doris, \& The Moral Psychology Research Group (Eds.), The Moral Psychology Handbook (pp. 147-205). Oxford: Oxford University Press. http://dx.doi.org/10.1093/acprof:oso/9780199582143.003.0006

Sundblad, E.-L., Biel, A., \& Gärling, T. (2007). Cognitive and Affective Risk Judgments Related to Climate Change. Journal of Environmental Psychology, 27, 97-106. http://dx.doi.org/10.1016/j.jenvp.2007.01.003

Sundblad, E.-L., Biel, A., \& Gärling, T. (2009). Knowledge and Confidence in Knowledge about Climate Change among Experts, Journalists, Politicians, and Laypersons. Environment and Behavior, 41, 281-302. http://dx.doi.org/10.1177/0013916508314998

Swim, J. K., Stern, P. C., Doherty, T. J., Clayton, S., Reser, J. P., Weber, E. U., Gifford, R., \& Howard, G. S. (2011). Psychology's Contributions to Understanding and Addressing Global Climate Change. American Psychologist, 66, $241-250$. 
http://dx.doi.org/10.1037/a0023220

Tabachnick, B. G., \& Fidell, L. S. (1989). Using Multivariate Statistics. New York: Harper \& Row, Publishers, Inc.

UNCED (United Nations Conference on Environment and Development) (1992). Convention on Biological Diversity. Rio de Janeiro: UNCED.

UNWTO (2008). Climate Change and Tourism: Responding to Global Challenges. Madrid: World Tourism Organization and United Nations Environment.

Van Vugt, M (2002). Central, Individual, or Collective Control? Social Dilemma Strategies for Natural Resource Management. American Behavioral Scientist, 45, 783-800. http://dx.doi.org/10.1177/0002764202045005004

Wade-Benzoni, K. A., \& Tost, L. P. (2009). The Egoism and Altruism of Intergenerational Behavior. Personality and Social Psychology Review, 13, 165-193. http://dx.doi.org/10.1177/1088868309339317

Weaver, D. (2006). Sustainable Tourism: Theory and Practice. London: Butterworth-Heinemann.

Weber, E. U. (2006). Experience-Based and Description-Based Perceptions of Long-Term Risk: Why Global Warming Does Not Scare Us. Climatic Change, 77, 103-120. http://dx.doi.org/10.1007/s10584-006-9060-3

Willms, J. (2007). Climate Change = Tourism Change? The Likely Impacts of Climate Change on Tourism in Germanys North Sea Coast Destinations. In A. Matzarakis, C. R. De Freitas, \& D. Scott (Eds.), Developments in Tourism Climatology (pp. 246-253). Freiburg: Freiburg University Press.

Wilson, K. M. (2000). Drought, Debate, and Uncertainty: Measuring Reports Knowledge and Ignorance about Climate Change. Public Understanding of Science, 9, 1-13. http://dx.doi.org/10.1088/0963-6625/9/1/301

World Resource Institute (WRI) (2000). World Resources 2000-2001-People and Ecosystems: The Fraying Web of Life. http://www.wri.org/publication/world-resources-2000-2001 